\title{
Oxidative stress induced Interleukin-32 mRNA expression in human bronchial epithelial cells
}

\author{
Megumi Kudo', Emiko Ogawa ${ }^{1,2,4^{*}}$, Daisuke Kinose ${ }^{1}$, Akane Haruna ${ }^{1}$, Tamaki Takahashi ${ }^{1}$, Naoya Tanabe ${ }^{1}$, \\ Satoshi Marumo ${ }^{1}$, Yuma Hoshino', Toyohiro Hirai ${ }^{1}$, Hiroaki Sakai ${ }^{3}$, Shigeo Muro ${ }^{1}$, Hiroshi Date ${ }^{3}$ and \\ Michiaki Mishima'
}

\begin{abstract}
Background: Chronic obstructive pulmonary disease (COPD) is characterized by airflow obstruction and persistent inflammation in the airways and lung parenchyma. Oxidative stress contributes to the pathogenesis of COPD. Interleukin (IL)-32 expression has been reported to increase in the lung tissue of patients with COPD. Here, we show that IFN $\gamma$ upregulated IL-32 expression and that oxidative stress augmented IFN $\gamma$-induced-IL-32 expression in airway epithelial cells. We further investigated transcriptional regulation responsible for IFN $\gamma$ induced IL-32 expression in human airway epithelial cells.
\end{abstract}

Methods: Human bronchial epithelial (HBE) cells were stimulated with $\mathrm{H}_{2} \mathrm{O}_{2}$ and IFN $\gamma$, and IL-32 expression was evaluated. The cell viability was confirmed by MTT assay. The intracellular signaling pathways regulating IL-32 expression were investigated by examining the regulatory effects of MAPK inhibitors and JAK inhibitor after treatment with $\mathrm{H}_{2} \mathrm{O}_{2}$ and IFN $\gamma$, and by using a ChIP assay to identify transcription factors (i.e. c-Jun, CREB) binding to the IL-32 promoter. Promoter activity assays were conducted after mutations were introduced into binding sites of c-Jun and CREB in the IL-32 promoter. IL-32 expression was also examined in HBE cells in which the expression of either c-Jun or CREB was knocked out by siRNA of indicated transcription factors.

Results: There were no significant differences of cell viability among groups. After stimulation with $\mathrm{H}_{2} \mathrm{O}_{2}$ or IFN $\gamma$ for 48 hours, IL-32 expression in HBE cells was increased by IFN $\gamma$ and synergistically upregulated by the addition of $\mathrm{H}_{2} \mathrm{O}_{2}$. The $\mathrm{H}_{2} \mathrm{O}_{2}$ augmented IFN $\gamma$ induced IL-32 mRNA expression was suppressed by a JNK inhibitor, but not by MEK inhibitor, p38 inhibitor, and JAK inhibitor I. Significant binding of c-Jun and CREB to the IL-32 promoter was observed in the IFN $\gamma+\mathrm{H}_{2} \mathrm{O}_{2}$ stimulated $\mathrm{HBE}$ cells. Introducing mutations into the c-Jun/CREB binding sites in the IL-32 promoter prominently suppressed its transcriptional activity. Further, knocking down CREB expression by siRNA resulted in significant suppression of IL-32 induction by IFN $\gamma$ and $\mathrm{H}_{2} \mathrm{O}_{2}$ in $\mathrm{HBE}$ cells.

Conclusion: IL-32 expression in airway epithelium may be augmented by inflammation and oxidative stress, which may occur in COPD acute exacerbation. C-Jun and CREB are key transcriptional factors in IFN $\gamma$ and $\mathrm{H}_{2} \mathrm{O}_{2}$ induced IL-32 expression.

Keywords: COPD, acute exacerbation, IFNY

\section{Background}

Chronic obstructive pulmonary disease (COPD) is characterized by non-fully reversible airflow obstruction and persistent inflammation in the airways and lung parenchyma [1-3]. Airway epithelial cells are one of the

\footnotetext{
* Correspondence: eogawa@belle.shiga-med.ac.jp

'Department of Respiratory Medicine, Kyoto University Graduate School of Medicine, Kyoto, Japan

Full list of author information is available at the end of the article
}

most important sources of inflammatory mediators that play important roles in the pathogenesis of COPD. Several reports have indicated that various factors such as smoking, infection, and proteases activate airway epithelial cells in COPD patients [2,4-6] and this is followed by the secretion of chemokines (CCL2, CXCL5, and CXCL10), inflammatory cytokines (TNF $\alpha$, IL (interleukin)-7 family members (TSLP), and IL-12), and growth
Ciomed Central

(c) 2012 Kudo et al; licensee BioMed Central Ltd. This is an Open Access article distributed under the terms of the Creative Commons Attribution License (http://creativecommons.org/licenses/by/2.0), which permits unrestricted use, distribution, and reproduction in any medium, provided the original work is properly cited. 
factors (GM-CSF and TGF- $\beta$ ) $[1,7,8]$ by these activated cells.

Cigarette smoke contains oxidants and free radicals, many of which remain in the airway for long periods $[9,10]$, is a major source of the oxidative stress that contributes to the pathogenesis of COPD. Also, activated inflammatory cells such as alveolar macrophages, neutrophils, eosinophils, monocytes, lymphocytes, and epithelial cells in the airways of COPD patients generate reactive oxidant species in response to inflammatory mediators [10].

IL-32, which was originally reported as natural killer cell transcript 4 , is known to be expressed in mononuclear cells, $\mathrm{T}$ cells, epithelial cells, and endothelial cells in human tissues [11-14]. Cytokines such as IFN $\gamma$ and TNF $\alpha$ promote IL-32 expression in these cells [15]. Lipopolysaccharide (LPS) also upregulates IL-32 expression in human mononuclear cells [16]. On the other hand, IL-32 induces monocytes and macrophages to produce inflammatory cytokines including TNF $\alpha, \mathrm{IL}-1 \beta$, IL-6, IL-4, MIP, IFN $\gamma$, and IL-8 and also regulates T cell apoptosis and monocyte differentiation to macrophages [16-18].

IL-32 has also been reported to be associated with the pathogenesis of inflammatory bowel disease and rheumatoid arthritis [12,14]. Recently, it was reported that the expression of IL-32 was increased in macrophages and airway epithelial cells in the lung tissues of COPD patients compared to that in the lungs of control smokers and non-smoking subjects. Furthermore, this IL-32 expression was reported to be negatively correlated with FEV1 and positively correlated with the expression levels of TNF $\alpha$ and CD8 [19]. However, the mechanisms of IL-32 gene regulation in the lungs of COPD patients are still unknown.

In this study, we evaluated whether oxidative stress affects IL-32 expression induced by IFN $\gamma$ and determined a mechanism by which this expression is regulated using a human bronchial epithelial (HBE) cell culture system.

\section{Methods}

\section{Reagents}

IFN $\gamma$ was obtained from Peprotech (Rocky Hill, NJ, USA). The JNK inhibitor SP600125 was from SABioscience (Frederick MD, USA), the MEK1 inhibitor PD98059 was purchased from Invitrogen (Carlsbad, CA, USA), and the p38 inhibitor SB203580 was from Enzo Life Sciences (Plymouth meeting, PA, USA). JAK inhibitor SC204021 was from Santa Cruz Biotechnology (Santa Cruz, CA, USA). The antibodies used were as follows: anti-human IL-32 monoclonal antibody, \#KU3252 , was from Biolegend (San Diego, CA, USA); anti- $\beta$ actin polyclonal antibody was from Imgenex (San Diego,
CA, USA); anti-c-Jun antibody and anti-CREB antibody were from Cell Signaling Technology (Danvers, MA, USA); and anti-RNA polymerase II antibody was from Santa Cruz Biotechnology (Santa Cruz). CREB and c-Jun siRNA were from Cell Signaling Technology. Control siRNA was from Invitrogen.

\section{Human bronchial epithelial (HBE) cells}

HBE cells were provided from the Lung Registry of Kyoto University. The Kyoto University review board for human studies approved the protocols employed in this study, and written informed consent was obtained from all patients. Briefly, HBE cells were isolated from patients who underwent lung lobectomy for tumor resection at Kyoto University Hospital and cultured in LHC-9 medium, (Invitrogen, Carlsbad, CA, USA). The patients were all never smokers with normal pulmonary function and had no history of pulmonary diseases. The cells were isolated from the portions of bronchus that were not involved in tumor according to a modified version of a previous method [20].

\section{Cell culture}

All experiments were carried out using cells at passages 1 to 4 . To get rid of corticosteroid from the media, HBE cells were cultured in corticosteroid-free Bronchial/Tracheal Epithelial Cell Basal Medium with growth factors (BEGM) (Lonza, Basel, Switzerland) instead of using LHC-9 for 24 hours prior to IFN $\gamma$ stimulation. For $\mathrm{H}_{2} \mathrm{O}_{2}$ treatment, the indicated concentration of $\mathrm{H}_{2} \mathrm{O}_{2}$ was added to the medium 2 hours before stimulation with $10 \mathrm{ng} / \mathrm{mL}$ IFN $\gamma$. To determine the effect of modulating MAPK activity on $\mathrm{H}_{2} \mathrm{O}_{2}$ augmented IFN $\gamma$ induced IL-32 mRNA expression, $10 \mu \mathrm{M}$ of JNK inhibitor, 20 $\mu \mathrm{M}$ of MEK inhibitor, $10 \mu \mathrm{M}$ of p38 inhibitor, $5 \mu \mathrm{M}$ JAK inhibitor I, or DMSO as the vehicle were added to the cell culture media 2 hours before IFN $\gamma$ stimulation. In all the treatments, the final concentration of DMSO was less than $0.075 \%$.

\section{MTT cell growth assay}

After stimulation with $250 \mu \mathrm{M} \mathrm{H}_{2} \mathrm{O}_{2}, 500 \mu \mathrm{M} \mathrm{H}_{2} \mathrm{O}_{2}, 10$ $\mathrm{ng} / \mathrm{ml} \mathrm{IFN} \gamma$ or $250 \mu \mathrm{M} \mathrm{H}_{2} \mathrm{O}_{2}$ and $10 \mathrm{ng} / \mathrm{ml} \mathrm{IFN} \gamma$ for 48 hours, the viability of the cells were examined using MTT cell growth assay kit (Millipore, Billerica, MA, USA) according to the manufacturer's instruction.

\section{RNA isolation and quantitative real-time PCR}

RNA was extracted from the HBE cells after $\mathrm{H}_{2} \mathrm{O}_{2}$ treatment plus 4, 8, and 24 hours of IFN $\gamma$ stimulation using TRIzol reagent ${ }^{\circledR}$ (Invitrogen) according to the manufacturer's protocol. Quantitative real-time PCR was carried out to determine IL-32 gene expression and $\beta$-actin gene expression as an internal control using the ABI- 
PRISM7300 Sequence-Detection-System (Applied Biosystems). The PCR primers used to detect all splice variants [21] of IL-32 mRNA and the $\beta$-actin mRNA were as follows: forward primer for IL-32, 5'-ATC CTC AAC ATC CGG GAC AG-3'; reverse primer for IL-32, 5'ATG AGG AGC AGC ACC CAG A-3'; forward primer for $\beta$-actin, 5'-CCG ATC CAC ACG GAG TAC TTG-3; reverse primer for $\beta$-actin, 5'-CCG ATC CAC ACG GAG TAC TTG-3'.

\section{Protein extraction and Western blot analysis}

$\mathrm{HBE}$ cell lysate protein was extracted after $\mathrm{H}_{2} \mathrm{O}_{2}$ treatment plus 48 hours IFN $\gamma$ stimulation. HBE cells were lysed in RIPA buffer (50 mM Tris $\mathrm{HCl}, 150 \mathrm{mM} \mathrm{NaCl}$, $1 \%$ TritonX) together with protease inhibitor cocktail (SIGMA, St. Louis, MO, USA). Twenty $\mu$ g of proteins were electrophoresed on SDS/15\% polyacrylamide gels and transferred to nitrocellulose membranes. IL-32 and $\beta$-actin were detected using specific antibodies.

\section{Chromatin immunoprecipitation assays}

Chromatin immunoprecipitation assays were performed using the Low Cell ChIP kit ${ }^{\circledR}$ (Nippongene, Tokyo, Japan) according to the manufacturer's protocol. Briefly, $\mathrm{HBE}$ cells were treated with or without $\mathrm{H}_{2} \mathrm{O}_{2}$ and/or IFN $\gamma$ for 30 minutes, and then the cells were fixed with formaldehyde to cross-link proteins with DNA. The reaction was quenched by 5 minutes treatment with 1.25 M glycine. Then, the cells were lysed, and chromatin molecules were sonicated to a length of between 200 and 1000 bps. The sonicated chromatin was incubated overnight at $4^{\circ} \mathrm{C}$ with magnetic bead-bound antibodies against c-Jun, CREB, RNA polymerase II or normal rabbit IgG as a negative control. After being washed, the immunoprecipitated chromatins were reverse crosslinked, and the recovered DNA was purified for realtime PCR. The PCR primers used to amplify the c-Jun and CREB binding sites in the IL-32 promoter region, which are located between nucleotides -96 to 134 , relative to the transcription start site at +1 , were designed according to the NM_ 001012631 NCBI sequence. The PCR primers used were as follows: the forward primer, 5'-CAA GGA CAG GGT CCA AAT TC-3', and the reverse primer, 5'-GGT CCG TCC CTG GCT GGG C3',

\section{Mutagenesis of the IL-32 promoter sequence and luciferase reporter assays}

We generated an IL-32 promoter construct with the sequence between nucleotides -120 and +530 relative to the transcription start site at +1 of the IL- 32 gene containing the c-Jun/CREB consensus sequence by PCR using human genomic DNA as a template. The PCR primers used were as follows: the forward primer, 5'-TGA
TCC AGA AGT TTC TCT GGC CTC TGG A-3', and the reverse primer, 5'-GCA GCC TCT CAC TCA CCT TCG-3', and a 4 bp mutation described in a previous report [22] was introduced into the c-Jun/CREB consensus sequence. Briefly, the TGACGTCA sequence which contains the tgacgtca c-Jun and tggctgacgtcacctt CREB consensus binding sequences and which is located from nucleotides -30 to -23 in the IL-32 gene promoter was changed to TcaatTCA using PCR primers that included these changes. Promoter constructs with mutated or respective wild-type sequences were ligated into the cloning vector and amplified in E.coli. As the cloned promoter sequences (with or without the mutation) were located between XhoI and HindIII restriction sites, the restriction enzyme (XhoI and HindIII) -treated promoter sequences were ligated with firefly luciferase coding reporter vectors (pGL4.10[luc2], Promega, Madison WI, USA) and referred to as pWild-Luc (without the mutation) and pMutant-Luc (with the mutation), respectively. All constructs were verified by sequencing.

To determine the transcriptional activity of these IL32 promoter constructs, HBE cells plated at $0.5 \times 10^{5}$ cells/well in 12-well plates were transiently transfected with $1 \mu \mathrm{g}$ of either pWild-Luc or pMutant-Luc per well using PrimeFect II (Takara, Otsu, Japan) according to the manufacturer's protocol. The cells were then cotransfected with $0.5 \mu \mathrm{g} /$ well of the Renilla luciferase reporter construct (pGL4.74[hRluc/TK], Promega) to normalize for differences in transfection efficiency between wells. After 2 hours of transfection, the medium was replaced with corticosteroid-free BEGM. Sixteen hours after transfection, the cells were pretreated with $250 \mu \mathrm{M} \mathrm{H}_{2} \mathrm{O}_{2}$ for 2 hours and then stimulated with $10 \mathrm{ng} / \mathrm{mL}$ of IFN $\gamma$. Six hours after the IFN $\gamma$ stimulation, the cells were lysed with Passive Lysis Buffer (Promega). Luciferase assays were performed using the Dual luciferase reporter assay system ${ }^{\circledR}$ (Promega), and the expression of firefly and Renilla luciferase was measured with a luminometer (Lumat LB $9507^{\circledR}$, Bethold, Bad Wildbad, Germany). Firefly luciferase activity was measured by adding luciferase assay reagent II (LARII, Promega), and Renilla luciferase was measured in a separate tube by adding LARII and Stop \& Glo reagent (Promega).

\section{Knockdown of c-Jun and CREB by siRNA transfection into HBE cells}

To confirm a role of c-Jun and/or CREB in $\mathrm{H}_{2} \mathrm{O}_{2}$ and IFN $\gamma$ induced IL-32 gene regulation, c-Jun or CREB was knocked out in HBE cells using either c-Jun siRNA or CREB siRNA. HBE cells were incubated with the indicated siRNA and transfection reagent (Lipofectamine RNAiMAX, Invitrogen) for 24 hours. Then cells were stimulated with $\mathrm{H}_{2} \mathrm{O}_{2}$ for 2 hours and then with IFN $\gamma$ 
for 24 hours before extraction of mRNA for evaluation of IL-32 by real time RT-PCR.

\section{Statistical analysis}

Analysis of variance (ANOVA) with the post hoc Fisher's test was used for comparisons among groups. All analyses were performed using GraphPad Prism Ver.4 (Graphpad software, San Diego, CA, USA). Values of $\mathrm{p}$ $<0.05$ were considered statistically significant.

\section{Results}

\section{$\mathrm{H}_{2} \mathrm{O}_{2}$ augmented IFN $\gamma$-induced IL-32 expression in HBE cells}

The influence of the $\mathrm{H}_{2} \mathrm{O}_{2}$ concentration on the cell death of HBE cells was determined. Although treatment with $500 \mu \mathrm{M} \mathrm{H}_{2} \mathrm{O}_{2}$ resulted in cell death, treatment with $250 \mu \mathrm{M} \mathrm{H}_{2} \mathrm{O}_{2}$ did not (data not shown). The cells were confirmed to be alive at least 48 hours after stimulation with $250 \mu \mathrm{M} \mathrm{H}_{2} \mathrm{O}_{2}$ and/or $10 \mathrm{ng} / \mathrm{ml}$ IFN $\gamma$ and the viability of the cells were confirmed by MTT assay (Figure 1A). After these preliminary experiments, we used $\mathrm{H}_{2} \mathrm{O}_{2}$ at a concentration of $250 \mu \mathrm{M}$ for 2 hours prior to IFN $\gamma$ stimulation in the rest of our investigations.

As shown in Figure 1B, IL-32 mRNA expression was upregulated by IFN $\gamma$ stimulation time dependently. After 4 and 8 hours stimulation with IFN $\gamma$, IL-32 mRNA expression was increased by 3.6 and 6.7 times, respectively, compared with control. Furthermore, IL-32 mRNA expression was increased by 4.9 and 11.0 times after 4 and 8 hours by IFN $\gamma$ with $\mathrm{H}_{2} \mathrm{O}_{2}$. However, synergistic upregulation by $\mathrm{H}_{2} \mathrm{O}_{2}$ was not significant at both times. Twenty four hours stimulation with IFN $\gamma$ alone significantly upregulated IL-32 mRNA expression in HBE cells. Pretreatment with $250 \mu \mathrm{M} \mathrm{H}_{2} \mathrm{O}_{2}$ in addition to IFN $\gamma$ synergistically upregulated IL-32 mRNA expression, although $\mathrm{H}_{2} \mathrm{O}_{2}$ alone did not influence its expression.

To determine the protein expression of IL-32 in HBE cells, Western blot analyses were performed using whole cell lysates from HBE cells treated with or without $\mathrm{H}_{2} \mathrm{O}_{2}$ and/or 48 hours of IFN $\gamma$ stimulation. The antibody used for detecting IL-32 protein recognizes the 4 splice variants of IL-32, $\alpha, \beta, \gamma$, and $\delta$. However, the difference in size between IL-32 $\beta$ and $\delta$ was so small, it was hard to distinguish between the two in the Western blotting analyses. As shown in Figure 1C, bands appeared at 22 and $26 \mathrm{kDa}$, which represented IL-32 $\beta$ and/or $\delta$, and IL-32 $\gamma$, respectively. IL-32 $\alpha$ could not be detected, suggesting that it is weakly expressed in $\mathrm{HBE}$ cells.
(A)

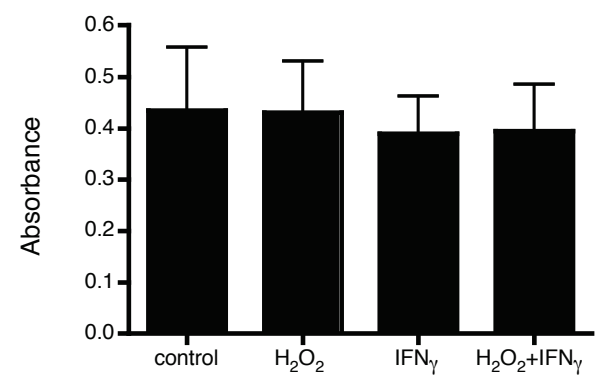

(B)

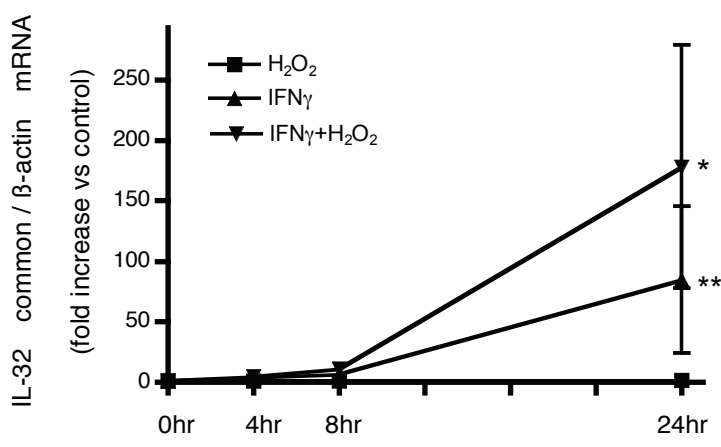

(C)

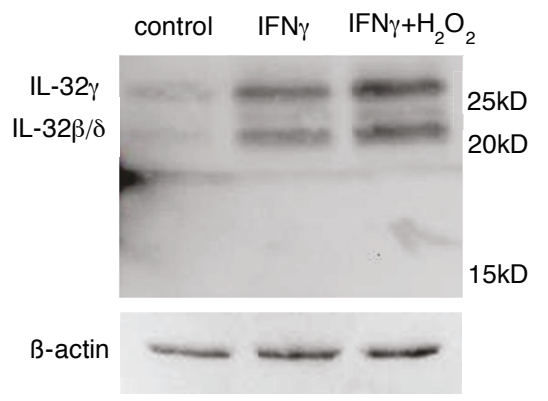

Figure 1 Cell viability and IL-32 expression in IFN $\gamma$ and $\mathrm{H}_{2} \mathrm{O}_{2}+$ IFN $\gamma$ stimulated $\mathrm{HBE}$ cells. HBE cells were incubated with $10 \mathrm{ng} /$ $\mathrm{ml}$ IFN $\gamma$ or $250 \mu \mathrm{M} \mathrm{H}_{2} \mathrm{O}_{2}$ and $10 \mathrm{ng} / \mathrm{ml}$ IFN $\gamma$ for 48 hours. The viability of the cells was examined using MTT assay (A). HBE cells were incubated with or without 2 hour $-\mathrm{H}_{2} \mathrm{O}_{2}$ pretreatment and then with or without IFN $\gamma$ stimulation for $0,4,8$, and 24 hours. The expression levels of IL-32 mRNA adjusted with expression levels in non-stimulated cells in each time point were determined by quantitative real-time PCR. HBE cells stimulated with $\mathrm{H}_{2} \mathrm{O}_{2}$, with IFNy, and with IFN $\gamma$ and $\mathrm{H}_{2} \mathrm{O}_{2}$, were presented in square plots, triangle plots, and inverted-triangle plots, respectively in graph (B). The bars show the means \pm SE from data performed on 3 different individuals. ${ }^{*} p<0.01$ significantly different. (C) After 48 hours of IFN $\gamma$ treatment $20 \mu \mathrm{g}$ of cell lysates were subjected to Western blotting. The $22 \mathrm{kDa}$ band represents $\mathrm{IL}-32 \beta / \delta$ protein, and the 26 $\mathrm{kDa}$ band represents $\mathrm{IL}-32 \gamma$ protein. The results shown are representative of 3 independent experiments. 
IFN $\gamma$ induced IL-32 expression was suppressed by inhibiting the JNK pathway

To investigate which signaling pathways are responsible for regulating IL-32 in HBE cells, we examined the effects of MAPK inhibitors selective for JNK, MEK1, and p38 on $\mathrm{H}_{2} \mathrm{O}_{2}$ and/or IFN $\gamma$ induced IL-32 mRNA expression in HBE cells (Figures 2A, B, and 2C). JNK inhibitor exerted an inhibitory effect on both IFN $\gamma$ alone (Figure 2B) and IFN $\gamma$ combined with $\mathrm{H}_{2} \mathrm{O}_{2}$ induced IL32 mRNA expression (Figures 2A and 2B). However, neither MEK1 inhibitor nor p38 inhibitor affected the mRNA expression of IL-32 (Figure 2A).

There was no effect of JAK inhibitor I on both IFN $\gamma$ alone and IFN $\gamma$ combined with $\mathrm{H}_{2} \mathrm{O}_{2}$ induced IL-32 mRNA expression (Figure 2C).

\section{Stimulation of $\mathrm{HBE}$ cells by $\mathrm{H}_{2} \mathrm{O}_{2}$ followed by IFN $\gamma$ promotes binding of transcription factors to the IL-32 promoter}

As shown in Figure 3A, c-Jun binding to the IL-32 promoter was only increased by the combined treatment of $\mathrm{H}_{2} \mathrm{O}_{2}$ followed by IFN $\gamma$, but not with $\mathrm{H}_{2} \mathrm{O}_{2}$ or IFN $\gamma$ alone.

CREB binding to the IL-32 promoter was significantly increased in the IFN $\gamma$ alone as well as with $\mathrm{H}_{2} \mathrm{O}_{2}$ followed by IFN $\gamma$ (Figure 3B). As expected, $\mathrm{H}_{2} \mathrm{O}_{2}$ alone did not increase CREB binding to the IL-32 promoter.

RNA polymerase II binding to the IL-32 promoter was increased in the IFN $\gamma$ treated cells and was further increased in the $\mathrm{H}_{2} \mathrm{O}_{2}+\mathrm{IFN} \gamma$ stimulated HBE cells (Figure $3 \mathrm{C}$ ) These results are consistent with our results regarding the transcriptional activity of IL-32.

\section{Mutations in the c-Jun/CREB binding site of the IL-32} promoter largely suppressed its transcriptional activity To confirm the roles of c-Jun and CREB in IL-32 gene transcription, which were indicated by ChIP assays, the transcriptional activity of IL-32 promoter with mutations in the c-Jun/CREB binding site was investigated. Compared to the wild-type promoter, the transcriptional activity of the mutant promoter was significantly reduced even in unstimulated HBE cells (control) and, while the wild-type promoter activity was increased by the combined stimuli of $\mathrm{H}_{2} \mathrm{O}_{2}$ followed by IFN $\gamma$ no increase was found with promoter mutated at the c-Jun/ CREB binding site, neither with $\mathrm{H}_{2} \mathrm{O}_{2}$, IFN $\gamma$ alone, nor with the combination (Figure 4).

\section{Knockdown of CREB resulted in significant suppression of} IL-32 induction by oxidative stress and IFN $\gamma$

Knock down of c-Jun and CREB mRNA expressions by each siRNA transfection in HBE cells were confirmed by real time-PCR. Both were successfully suppressed up to $10 \%$ (Figures $5 \mathrm{~A}$ and $5 \mathrm{~B}$, respectively). Although

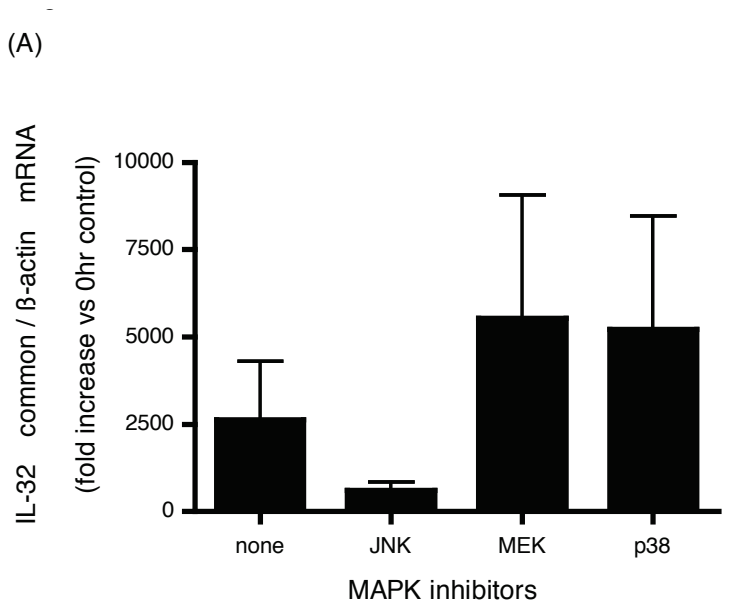

(B)

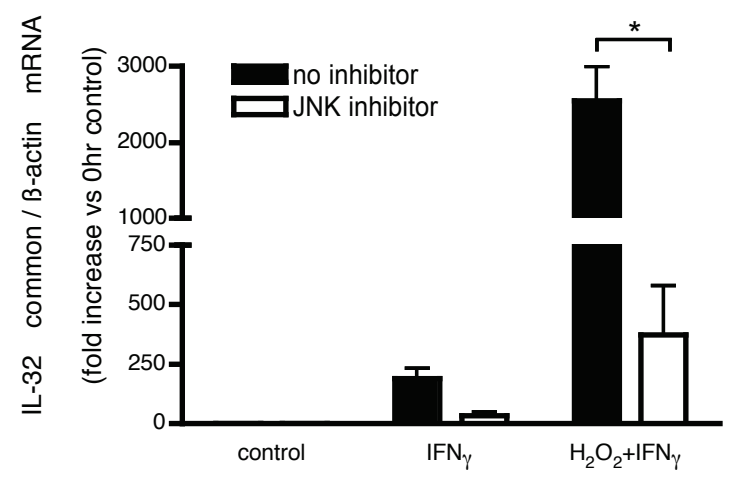

(C)

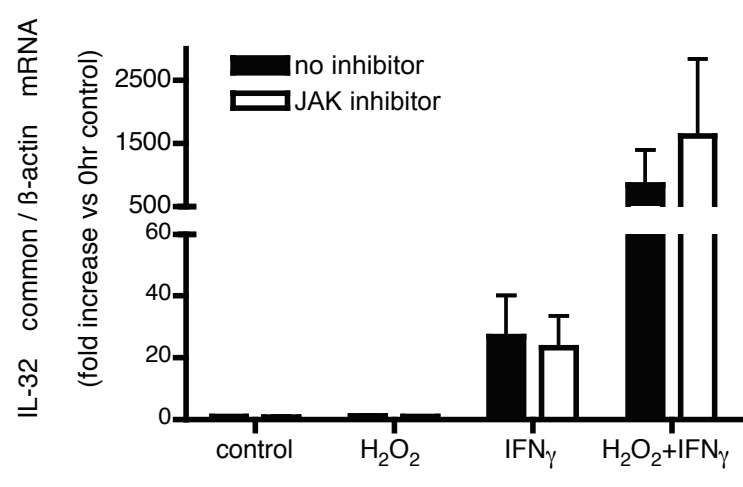

Figure 2 Influence of MAPK inhibitors on $\mathrm{H}_{2} \mathrm{O}_{2}+\mathrm{IFN} \gamma$ induced IL-32 mRNA expression in HBE cells. After treatment with the JNK inhibitor, the MEK inhibitor, the p38 inhibitor for 24 hours, IL-32 mRNA expression in $\mathrm{H}_{2} \mathrm{O}_{2}$ and IFN $\gamma$ stimulated HBE cells (A) and the effect of JNK inhibitor (B) or JAK inhibitor I (C) upon IL-32 expression stimulated by IFN $\gamma$ with or without $\mathrm{H}_{2} \mathrm{O}_{2}$ in $\mathrm{HBE}$ cells were examined by quantitative real-time PCR. All mRNA quantities were adjusted to the quantities at 0 hour control without stimulation. In graph (B) and (C), the closed bars represent the results of vehicle control and the open bars represent the results of JNK inhibitor (B) and JAK inhibitor (C). The bars show the means \pm SE from 3 different individuals. ${ }^{*} p<0.05$ significantly different. 


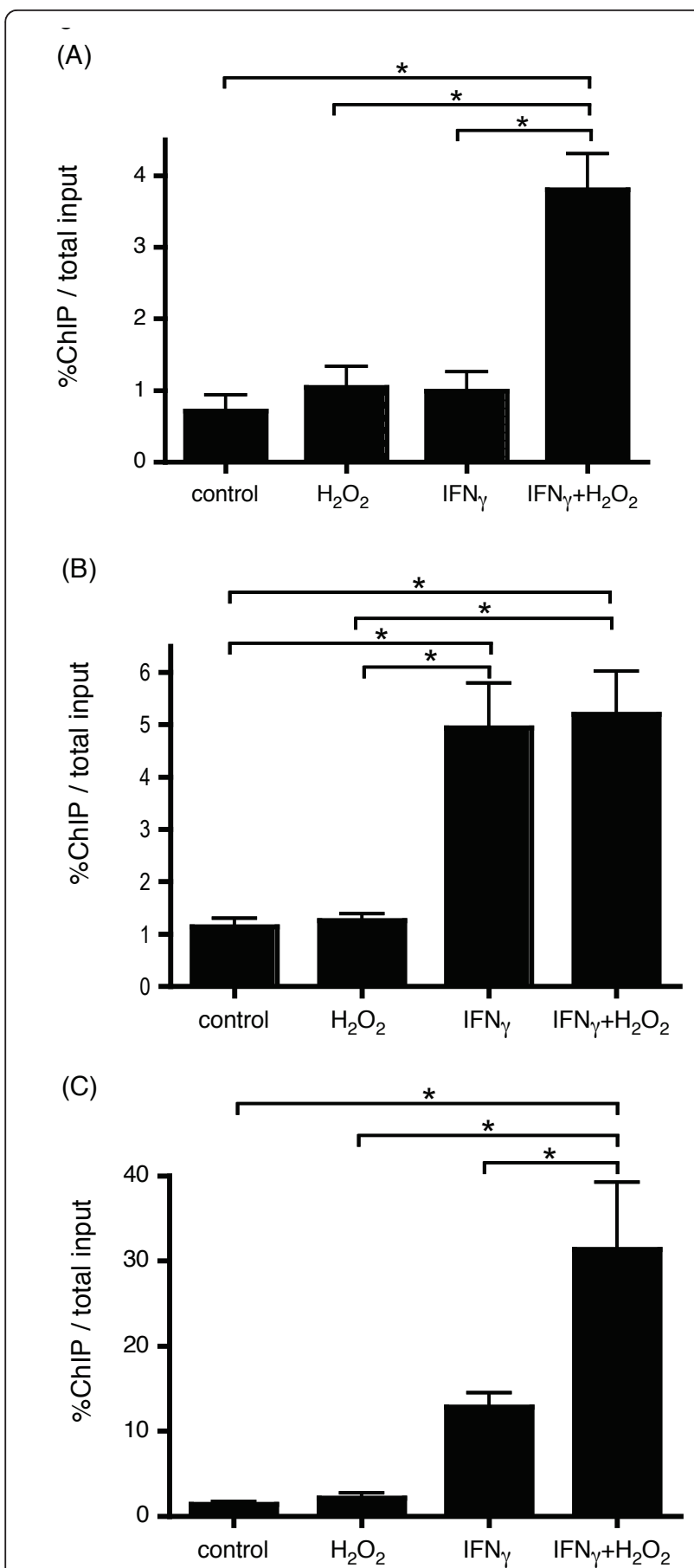

Figure 3 Transcription factors that bind to the IL-32 gene promoter. $\mathrm{HBE}$ cells were stimulated with $\mathrm{H}_{2} \mathrm{O}_{2}$ I IFN $\gamma_{1} \mathrm{H}_{2} \mathrm{O}_{2}+\mathrm{IFN} \gamma$, or vehicle for 30 minutes. The ChIP assay was performed to identify which transcription factors bind to the IL-32 gene promoter. Binding activity was compared using quantitative real-time PCR of the IL-32 promoter in DNA from chromatin complexes immunoprecipitated by antibodies to c-Jun (A), CREB (B), and RNA polymerase II (C). The bars show the means \pm SE from 3 different individuals. ${ }^{*} p<0.01$ significantly different.

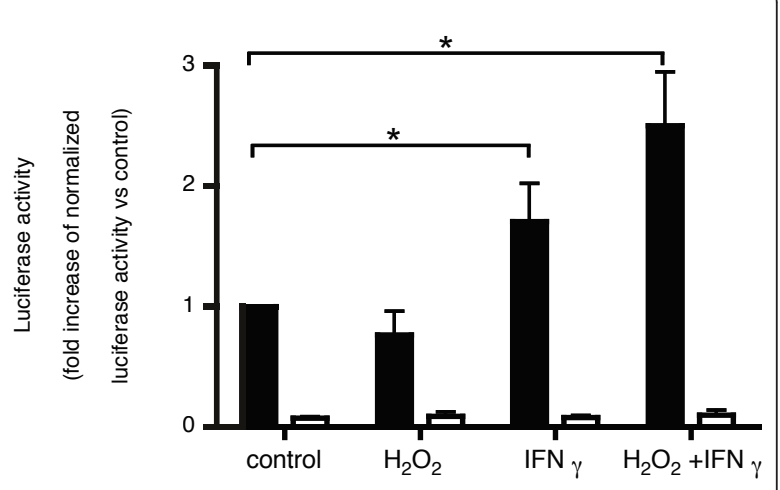

Figure 4 Transcriptional activity of promoter of IL-32 gene after IFN $\gamma$ or $\mathrm{H}_{2} \mathrm{O}_{2}+\mathrm{IFN} \gamma$ stimulation. HBE cells were transfected with a luciferase promoter vector without mutations (pWild-Luc), closed bars, or the same vector with mutations in the c-Jun/CREB binding site (pMutant-Luc), open bars. Cells were stimulated with $\mathrm{H}_{2} \mathrm{O}_{2}$, IFN $\gamma, \mathrm{H}_{2} \mathrm{O}_{2}+\mathrm{IFN}$, or vehicle. Six hours after indicated stimulation, the cells were lysed and luciferase activity was measured. Luciferase activity in the cells was normalized to Renilla luciferase activity. The bars represent the means \pm SE from 3 different individuals. ${ }^{*} p<0.05$ significantly different.

knockdown of c-Jun did not influence IL-32 induction by IFN $\gamma$ alone, as shown in Figure $5 \mathrm{C}$, it significantly suppressed $\mathrm{H}_{2} \mathrm{O}_{2}+$ IFN $\gamma$ induced IL-32 expression. On the other hand, knocking down of CREB resulted in significant suppression of IL-32 expression after stimulation with IFN $\gamma$ alone and also with $\mathrm{H}_{2} \mathrm{O}_{2}+$ IFN $\gamma$ compared with control.

\section{Discussion}

In this study, we revealed that IFN $\gamma$ upregulated IL-32 mRNA expression in $\mathrm{HBE}$ cells. Incubation with $\mathrm{H}_{2} \mathrm{O}_{2}$ alone did not upregulate its expression; however, pretreatment with $\mathrm{H}_{2} \mathrm{O}_{2}$ augmented IFN $\gamma$ induced IL-32 mRNA and expression in HBE cells. And IL-32 induction was suppressed by JNK inhibition but not by MEK inhibition or p38 ihnibition IFN $\gamma+\mathrm{H}_{2} \mathrm{O}_{2}$ stimulated HBE cells, indicating expression induction of IL-32 by IFN $\gamma$ is regulated by signal pathway involving JNK and independent of p38 or MEK. JNK inhibitor also inhibited IFN $\gamma$ induced IL-32. JAK inhibitor I did not affect both on IFN $\gamma$ alone and IFN $\gamma+\mathrm{H}_{2} \mathrm{O}_{2}$ induced IL-32. $\mathrm{H}_{2} \mathrm{O}_{2}$ alone did not increase c-Jun binding to the c-Jun binding site in the IL-32 promoter region. Binding of cJun was increased when HBE cells were stimulated with both $\mathrm{H}_{2} \mathrm{O}_{2}$ and IFN $\gamma$. On the other hand, CREB was able to bind to the IL-32 promoter after IFN $\gamma$ stimulation with or without $\mathrm{H}_{2} \mathrm{O}_{2}$. Mutations in the c-Jun and CREB binding sites in the IL-32 promoter region inhibited the promoter activity induced by IFN $\gamma$ with or without $\mathrm{H}_{2} \mathrm{O}_{2}$. Further, knocking down of c-Jun resulted in 


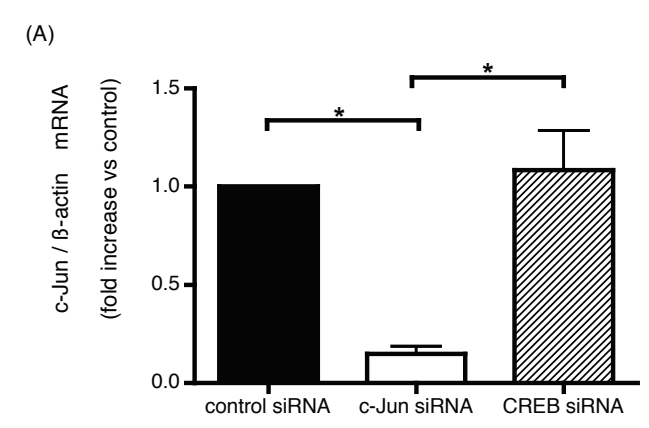

(B)

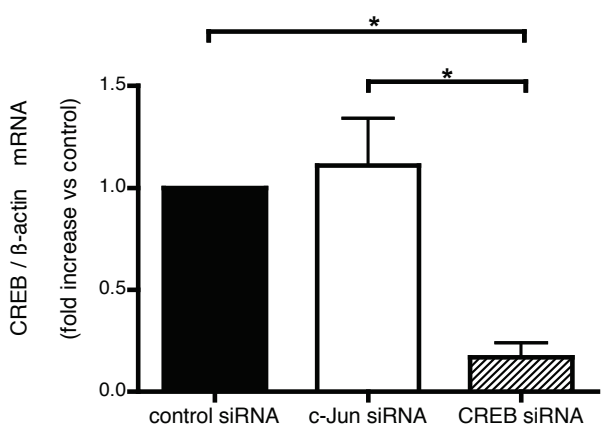

(C)

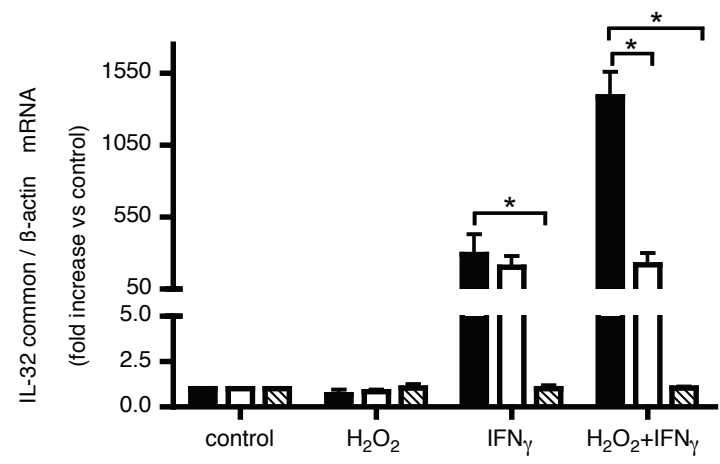

Figure 5 Knockdown efficiency of c-Jun and CREB mRNA and IL-32 expression induced by IFN $\gamma$ and $\mathrm{H}_{2} \mathrm{O}_{2}$ in $\mathrm{HBE}$ cells transfected with c-Jun or CREB siRNAs. C-Jun (A) and CREB (B) $m R N A$ expression levels examined by quantitative real time PCR in HBE cells transfected with indicated siRNAs. Expression levels of cJun (A) and CREB (B) by each siRNA transfection were looked by quantitative real time PCR. IL-32 expression was examined by real time PCR in HBE cells transfected with control-siRNA, closed bars, CJun-siRNA, open bars, or CREB-siRNA, hatched bars, respectively. Then 48 hours after transfection, cells were stimulated with $\mathrm{H}_{2} \mathrm{O}_{2}$ and/or IFN $\gamma$, followed by IL-32 quantitative real time PCR of RNA extracted 24 hours after the stimulation (C). The bars represent the means \pm SE from 3 different individuals. ${ }^{*} p<0.05$ significantly different.

suppressed induction of IL-32 mRNA expression by $\mathrm{H}_{2} \mathrm{O}_{2}+$ IFN $\gamma$ and knocking out of CREB resulted in suppressed induction by IFN $\gamma$ alone and by $\mathrm{H}_{2} \mathrm{O}_{2}+$ IFN $\gamma$. This indicates that c-Jun and CREB binding to the promoter are the key mechanisms of IL-32 induction by $\mathrm{H}_{2} \mathrm{O}_{2}$ and IFN $\gamma$.
Several previous reports have indicated that IL-32 expression was upregulated by Mycobacterium tuberculosis infection or LPS in peripheral blood mononuclear cells and was also upregulated by influenza and HIV virus infection in the A549 and HEK293T human embryonic kidney cell lines, respectively. In addition, LPS and phorbol myristate acetate induced IL-32 expression in a leukemia cell line and in endothelial cells [23-26]. Recently, Li et al. reported the regulatory effect of influenza A virus upon IL-32 expression, indicating that CREB and NF- $\kappa \mathrm{B}$ are the key molecules in the induction of IL-32 expression [27]. No previous reports have determined the regulatory effect of oxidative stress on IL-32 expression. In this study, oxidative stress; i.e., $\mathrm{H}_{2} \mathrm{O}_{2}$ treatment, did not affect IL-32 expression alone, but it did augment IFN $\gamma$-induced IL-32 expression in HBE cells.

Increased oxidative stress, an important aggravating factor of the disease, is persistent not only in the lungs of currently smoking COPD patients but also in patients who have achieved smoking cessation for years $[10,28]$. On the other hand, IFN $\gamma$ is known to be a representative cytokine of CD8+ T cells and is also associated with viral infection. Even in patients with stable COPD, IFN $\gamma$ levels were reported to be increased. Furthermore, viral infection is a major cause of COPD exacerbation $[29,30]$. Exacerbations appear to accelerate the decreasing of lung function in COPD [31]. Taken together with our findings that $\mathrm{H}_{2} \mathrm{O}_{2}$ did not affect IL-32 expression alone but did augment IFN $\gamma$-induced IL-32 expression, IL-32 could be induced higher in airways of COPD patients who have increased oxidative stress under the exacerbation caused by viral infection and/or an inflammatory condition in which CD8 $+\mathrm{T}$ cells are activated. This suggests a possible mechanism for the increased expression of IL-32 in severe COPD patients compared to mild COPD patients and non-COPD smokers, as Calabrese $\mathrm{F}$ et al. reported [19].

The mechanisms regulating IL-32 expression have been examined in several reports using vascular endothelial cells, synovial fibroblasts, and pancreatic cancer cell lines $[13,32,33]$. We investigated the mechanism regulating IL-32 expression in airway epithelial cells to clarify whether the same pathways are involved or whether characteristic features are seen according to cell type and to examine whether the blockade of certain signal pathways results in reduced expression of IL-32.

We have searched transcription factor binding sites existing on IL-32 promoter using sequence retrieval software TFSEARCH ${ }^{(\mathrm{TM})}$ [34], and two adjacent binding sites that could be responsible for the downstream of JNK signaling pathway are those of c-Jun and CREB, which are located between nucleotides -30 to -23 and 
-34 to -19 , respectively, as a transcription start site at +1 (Figure 6). As shown in Figure 6, there are consensus binding sites of ATF and NF $\kappa \mathrm{B}$ other than $\mathrm{C}$-Jun and CREB on IL-32 promoter region. The cellular signaling pathway induced by IFN $\gamma$ has been investigated in bronchial epithelial cell line (BEAS-2B) [35], which revealed that the signal was dependent on IKKB1/2 but not the $\mathrm{NF} \kappa \mathrm{B}$ pathway. In addition, IL-32 expression was not suppressed by an inhibitor of p38 which is supposed to be one of the kinases upstream of NF $\kappa \mathrm{B}$. For these reasons, NF $\kappa \mathrm{B}$ was thought to be not associated with IL-32 expression induced by IFN $\gamma$ (Figure 2A).

Further, a previous report showed that deletions of the IL-32 promoter sequence, including one of the consensus ATF binding sites, resulted in no decline in transcription activity [13]. Taking these results into consideration, we focused instead in our study on c-Jun and CREB as key molecules regulating IL-32 transcription induced by IFN $\gamma$ and oxidative stress.

In HBE cells, c-Jun does not bind to the IL-32 promoter in the absence of IFN $\gamma$. Although the phosphorylation of c-Jun after $\mathrm{H}_{2} \mathrm{O}_{2}$ stimulation has been fully investigated in previous reports [36-38], it is unclear whether $\mathrm{H}_{2} \mathrm{O}_{2}$ induces or suppresses c-Jun binding to a specific gene promoter. Kumar et al. revealed that $\mathrm{H}_{2} \mathrm{O}_{2}$ directly suppressed AP-1 binding to the eNOS promoter [39]. Our results suggested c-Jun could be responsible for the transcription activity of IL-32 when HBE cells were stimulated by $\mathrm{H}_{2} \mathrm{O}_{2}+\mathrm{IFN} \gamma$.

On the contrary, CREB bound to IL-32 promoter after IFN $\gamma$ stimulation with or without $\mathrm{H}_{2} \mathrm{O}_{2}$. CREB activation by IFN $\gamma$ has been reported previously in murine macrophages $[40,41]$, but a larger number of reports have indicated that IFN $\gamma$ has a suppressive effect on CREB activation $[42,43]$. There are no reports about $\mathrm{H}_{2} \mathrm{O}_{2}$ activating CREB binding to gene promoters. In our study, CREB was bound to the IL-32 promoter after

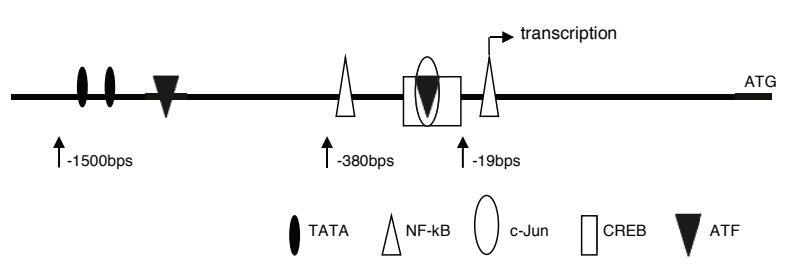

Figure 6 Major transcription factor binding sites in 1500 bps upstream from transcription start site of IL-32 gene promoter. NF-kappa B binding sites at nucleotide -9 to +5 and -361 to -352 , CREB binding site at nucleotide -34 to -19 , c-Jun/CREB binding site is at nucleotide -30 to -23 , ATF-2 binding sites at nucleotide -33 to -20 and, -769 to -759 , and TATA boxes at nucleotide -1215 to -1206 and -1502 to -1497 relative to the transcription start site at +1 . These binding sites were cited by using sequence searching software TFSEARCH ${ }^{(T M)}$
IFN $\gamma$ treatment but not after treatment with $\mathrm{H}_{2} \mathrm{O}_{2}$ alone. The activation and binding of CREB to the IL-32 promoter by IFN $\gamma$ is one possible mechanism of IL-32 gene regulation in $\mathrm{HBE}$ cells and another is that IFN $\gamma$ indirectly affects CREB activation through coactivators (e.g., CBP/p300) that are induced and activated by IFN $\gamma$ [44] or other transcription factors including STAT-1 $[45,46]$, which is the main downstream effector of IFN $\gamma$ stimulation. IFN $\gamma$ is known to exert its effect through not only JAK/STAT signal pathway but also through MAPK signaling pathway $[47,48]$. Some reports indicated presence of MAPK signal transduction by IFN $\gamma$ which is not suppressed by inhibiting JAK/STAT [49], and Kim HA et al found IFN $\gamma$ signal exerted by activation and upregulation of CREB but is not influenced by knocking out of STAT [40]. These research findings support our results that IL-32 expression regulation by IFN $\gamma$ can be dependent on JNK (and its downstream cJun and CREB) but be independent of JAK/STAT (Figure $2 \mathrm{C}$ ). Although no binding sites for STAT or interferon regulatory factor (IRF) were detected, but CREB binding site was detected at least within 1500 bps from transcription start site of IL-32 promoter, further investigation with the full length promoter will be needed to confirm whether the JAK/STAT pathways are involved or not.

As shown in Figure 4, mutations in the c-Jun/CREB binding sites resulted in markedly reduced transcription of IL-32, even after $\mathrm{H}_{2} \mathrm{O}_{2}$ and/or IFN $\gamma$ stimulation. This is consistent with a previous report investigating the regulatory mechanism of IL-32 transcription in endothelial cells by Kobayashi et al. [13]. They demonstrated that the deletion of the IL-32 promoter between nucleotides 26 and 100 upstream of the transcription initiation site, identical to the region containing the CREB and cJun binding sequences, led to significantly suppressed transcription activity. Further, knocking down of CREB by siRNA transfection resulted in a significant suppression of the IL-32 expression that was induced by both IFN $\gamma$ alone and IFN $\gamma+\mathrm{H}_{2} \mathrm{O}_{2}$ down to the baseline control levels. CREB is a key transcription factor for IL-32 transcription in HBE cells. This finding is also compatible with the report by $\mathrm{Li}$ et al. showing that mutations in the binding site for CREB or CREB knockdown resulted in the significant suppression of influenza $A$ virus-induced IL-32 transcription [27]. In addition, decreased expression of c-Jun by c-Jun siRNA resulted the significant suppression of IL-32 induction by IFN $\gamma+$ $\mathrm{H}_{2} \mathrm{O}_{2}$, though IL-32 induction by $\mathrm{H}_{2} \mathrm{O}_{2}$ or IFN $\gamma$ alone was not affected (Figure $5 \mathrm{C}$ ). These findings suggested synergistic effect of c-Jun inducing IL-32 expression by IFN $\gamma$ under oxidative stress.

Although p38 is suggested to be one of MAPKs located upstream of AP-1 (including C-Jun), we found 
no effect of p38 inhibitor on IL-32 induction by IFN $\gamma$ in HBE cells. This could be explained by number of reports showing that signal transduction induced by cytokines such as IFN $\gamma$ or oxidizing substance that involve AP-1 was dependent of JNK but was independent of p38 in HBE cells and macrophages [50,51]

Putting the results of our experiments together, we suggest that IFN $\gamma$ induced CREB binding to the IL-32 promoter, which was followed by an increase in the transcription of IL-32, and an additive effect of c-Jun binding to the IL-32 promoter by $\mathrm{H}_{2} \mathrm{O}_{2}$ resulted in a further acceleration of IL-32 transcription. How IFN $\gamma$ affects c-Jun binding to the promoter has not been clarified. One possibility is that it involves a coactivator, e.g. $\mathrm{CBP} / \mathrm{p} 300$, which is known to bind to AP-1 similar to cJun and promotes transcriptional activity [52]. CBP/ p300 could be activated by IFN $\gamma$ [49], and CREB could form a heterodimer with c-Jun [53], which may explain the necessity of IFN $\gamma$ for the binding of c-Jun to the IL32 promoter during $\mathrm{H}_{2} \mathrm{O}_{2}$ stimulation. In addition, both activated c-Jun and CREB binding to the IL-32 promoter are necessary to induce significant transcription of IL-32 in IFN $\gamma$ and $\mathrm{H}_{2} \mathrm{O}_{2}$ stimulated HBE cells.

The role of increased IL-32 expression in airway epithelial cells in the pathogenesis of COPD has not been clarified, and furthermore, it is still unclear whether suppressing its expression is beneficial with regards to preventing disease progression or improving the symptoms of the disease. IL-32 has several roles including inducing the expression of inflammatory cytokines and adhesion molecules in T-lymphocytes, monocytes, macrophages, and epithelial cells and promoting monocyte differentiation into macrophages, which alters the responses of inflammatory cells against infection $[54,55]$. Also, proteinase- 3 , which is activated by neutrophilic inflammation, cleaves IL-32 into its highly activated form $[17,56]$. Thus, increased IL-32 expression may modify airway inflammation in COPD. Further investigations to identify the roles of IL-32 in COPD are necessary.

As IL-32 is expressed in several types of cells, the mechanism of IL-32 gene regulation suggested in this study may not only be applicable to the pathogenesis of COPD but also those of other inflammatory diseases associated with oxidative stress. Further studies are needed.

\section{Abbreviations}

IL-32: interleukin-32; COPD: chronic obstructive pulmonary disease; HBE: human bronchial epithelial cell; ChIP: chromatin immunoprecipitation; CCL: CC chemokine ligand; CXCL: CXC chemokine ligand; TSLP: thymic stromal lymphopoietin; GM-CSF: granulocyte macrophage colony stimulating factor; LPS: lipopolysaccharide; $\mathrm{FEV}_{1}$ : forced expiratory volume in one second; DMSO: dimethyl sulfoxide; PCR: polymerase chain reaction; RT-PCR: Reverse
Transcription -polymerase chain reaction; eNOS: endothelial nitric oxide synthase.

\section{Acknowledgements}

We thank Ms. Aya Inazumi who helped us to maintain cell cultures and to prepare samples for Western blot analysis.

\section{Author details}

${ }^{1}$ Department of Respiratory Medicine, Kyoto University Graduate School of Medicine, Kyoto, Japan. ${ }^{2}$ Health Administration Center and Division of Respiratory Medicine, Department of Medicine, Shiga University of Medical Science, Otsu, Shiga, Japan. ${ }^{3}$ Department of thoracic surgery, Graduate School of Medicine, Kyoto University, Kyoto, Japan. ${ }^{4}$ Health Administration Center, Shiga University of Medical Science, Seta-Tsukinowa-cho, Otsu, Shiga 520-2192, Japan.

\section{Authors' contributions}

MK and EO performed the whole experiments. DK, AH, TT, NT and SM contributed in collecting clinical data and samples. HS and HD contributed in providing surgery samples. EO designed the study. DK, AH, $\Pi, N T, Y H, T H$, SM, and MM advised the design of the study and participated in the analysis of the data. All authors read and approved the final manuscript.

\section{Competing interests}

The authors declare that they have no competing interests.

Received: 20 December 2011 Accepted: 14 March 2012 Published: 14 March 2012

\section{References}

1. Barnes PJ: The cytokine network in chronic obstructive pulmonary disease. Am J Respir Cell Mol Biol 2009, 41(6):631-638.

2. Cosio MG, Saetta M, Agusti A: Immunologic aspects of chronic obstructive pulmonary disease. N Engl J Med 2009, 360(23):2445-2454.

3. Lopez AD, Shibuya K, Rao C, Mathers CD, Hansell AL, Held LS, Schmid V, Buist S: Chronic obstructive pulmonary disease: current burden and future projections. Eur Respir J 2006, 27(2):397-412.

4. Kouzaki H, O'Grady SM, Lawrence CB, Kita H: Proteases induce production of thymic stromal lymphopoietin by airway epithelial cells through protease-activated receptor-2. J Immunol 2009, 183(2):1427-1434.

5. Proud D, Chow CW: Role of viral infections in asthma and chronic obstructive pulmonary disease. Am J Respir Cell Mol Biol 2006, 35(5):513-518.

6. Richter A, O'Donnell RA, Powell RM, Sanders MW, Holgate ST, Djukanovic R, Davies DE: Autocrine ligands for the epidermal growth factor receptor mediate interleukin-8 release from bronchial epithelial cells in response to cigarette smoke. Am J Respir Cell Mol Biol 2002, 27(1):85-90.

7. Takizawa H, Tanaka M, Takami K, Ohtoshi T, Ito K, Satoh M, Okada Y, Yamasawa F, Nakahara K, Umeda A: Increased expression of transforming growth factor-beta1 in small airway epithelium from tobacco smokers and patients with chronic obstructive pulmonary disease (COPD). Am J Respir Crit Care Med 2001, 163(6):1476-1483.

8. Ying S, O'Connor B, Ratoff J, Meng Q, Fang C, Cousins D, Zhang G, Gu S, Gao Z, Shamji B, et al: Expression and cellular provenance of thymic stromal lymphopoietin and chemokines in patients with severe asthma and chronic obstructive pulmonary disease. J Immunol 2008, 181(4):2790-2798.

9. Nakayama T, Church DF, Pryor WA: Quantitative analysis of the hydrogen peroxide formed in aqueous cigarette tar extracts. Free Radic Biol Med 1989, 7(1):9-15.

10. Rahman I: Oxidative stress in pathogenesis of chronic obstructive pulmonary disease: cellular and molecular mechanisms. Cell Biochem Biophys 2005, 43(1):167-188.

11. Dahl CA, Schall RP, He HL, Cairns JS: Identification of a novel gene expressed in activated natural killer cells and T cells. J Immunol 1992, 148(2):597-603.

12. Joosten LA, Netea MG, Kim SH, Yoon DY, Oppers-Walgreen B, Radstake TR, Barrera P, van de Loo FA, Dinarello CA, van den Berg WB: IL-32, a proinflammatory cytokine in rheumatoid arthritis. Proc Natl Acad Sci USA 2006, 103(9):3298-3303. 
13. Kobayashi H, Lin PC: Molecular characterization of IL-32 in human endothelial cells. Cytokine 2009, 46(3):351-358.

14. Shioya M, Nishida A, Yagi Y, Ogawa A, Tsujikawa T, Kim-Mitsuyama S, Takayanagi A, Shimizu N, Fujiyama Y, Andoh A: Epithelial overexpression of interleukin-32alpha in inflammatory bowel disease. Clin Exp Immunol 2007, 149(3):480-486.

15. Goda C, Kanaji T, Kanaji S, Tanaka G, Arima K, Ohno S, Izuhara K: Involvement of IL32 in activation-induced cell death in T cells. Int Immunol 2006, 18(2):233-240

16. Netea MG, Lewis EC, Azam T, Joosten LA, Jaekal J, Bae SY, Dinarello CA, Kim SH: Interleukin-32 induces the differentiation of monocytes into macrophage-like cells. Proc Natl Acad Sci USA 2008, 105(9):3515-3520.

17. Novick D, Rubinstein M, Azam T, Rabinkov A, Dinarello CA, Kim SH: Proteinase 3 is an IL-32 binding protein. Proc Natl Acad Sci USA 2006, 103(9):3316-3321.

18. Shoda H, Fujio K, Yamaguchi Y, Okamoto A, Sawada T, Kochi Y, Yamamoto K: Interactions between IL-32 and tumor necrosis factor alpha contribute to the exacerbation of immune-inflammatory diseases. Arthritis Res Ther 2006, 8(6):R166.

19. Calabrese F, Baraldo S, Bazzan E, Lunardi F, Rea F, Maestrelli P, Turato G, Lokar-Oliani K, Papi A, Zuin R, et al: IL-32, a novel proinflammatory cytokine in chronic obstructive pulmonary disease. Am J Respir Crit Care Med 2008, 178(9):894-901.

20. Higashimoto Y, Elliott WM, Behzad AR, Sedgwick EG, Takei T, Hogg JC, Hayashi S: Inflammatory mediator mRNA expression by adenovirus E1Atransfected bronchial epithelial cells. Am J Respir Crit Care Med 2002, 166(2):200-207.

21. Kim SH, Han SY, Azam T, Yoon DY, Dinarello CA: Interleukin-32: a cytokine and inducer of TNFalpha. Immunity 2005, 22(1):131-142.

22. Cevik MO, Katsuyama M, Kanda S, Kaneko T, Iwata K, Ibi M, Matsuno K, Kakehi T, Cui W, Sasaki M, et al: The AP-1 site is essential for the promoter activity of NOX1/NADPH oxidase, a vascular superoxide-producing enzyme: Possible involvement of the ERK1/2-JunB pathway. Biochem Biophys Res Commun 2008, 374(2):351-355.

23. Kang JW, Choi SC, Cho MC, Kim HJ, Kim JH, Lim JS, Kim SH, Han JY, Yoon DY: A proinflammatory cytokine interleukin-32beta promotes the production of an anti-inflammatory cytokine interleukin-10. Immunology 2009, 128(1 Suppl):e532-540.

24. Li W, Liu Y, Mukhtar MM, Gong R, Pan Y, Rasool ST, Gao Y, Kang L, Hao Q, Peng $G$, et al: Activation of interleukin-32 pro-inflammatory pathway in response to influenza A virus infection. PLoS One 2008, 3(4):e1985.

25. Netea MG, Azam T, Lewis EC, Joosten LA, Wang M, Langenberg D, Meng X, Chan ED, Yoon DY, Ottenhoff $T$, et al: Mycobacterium tuberculosis induces interleukin-32 production through a caspase-1/IL-18/interferon-gammadependent mechanism. PLoS Med 2006, 3(8):e277.

26. Rasool ST, Tang H, Wu J, Li W, Mukhtar MM, Zhang J, Mu Y, Xing HX, Wu J, Zhu Y: Increased level of IL-32 during human immunodeficiency virus infection suppresses HIV replication. Immunol Lett 2008, 117(2):161-167.

27. Li W, Sun W, Liu L, Yang F, Li Y, Chen Y, Fang J, Zhang W, Wu J, Zhu Y: IL32: a host proinflammatory factor against influenza viral replication is upregulated by aberrant epigenetic modifications during influenza $\mathrm{A}$ virus infection. J Immunol 2010, 185(9):5056-5065.

28. Louhelainen N, Rytila P, Haahtela T, Kinnula VL, Djukanovic R: Persistence of oxidant and protease burden in the airways after smoking cessation. BMC Pulm Med 2009, 9:25.

29. Anzueto A, Sethi S, Martinez FJ: Exacerbations of chronic obstructive pulmonary disease. Proc Am Thorac Soc 2007, 4(7):554-564.

30. Moermans C, Heinen V, Nguyen M, Henket M, Sele J, Manise M, Corhay JL, Louis R: Local and systemic cellular inflammation and cytokine release in chronic obstructive pulmonary disease. Cytokine 2011, 56(2):298-304.

31. Kanner RE, Anthonisen NR, Connett JE: Lower respiratory illnesses promote FEV(1) decline in current smokers but not ex-smokers with mild chronic obstructive pulmonary disease: results from the lung health study. Am J Respir Crit Care Med 2001, 164(3):358-364.

32. Mun SH, Kim JW, Nah SS, Ko NY, Lee JH, Kim JD, Kim do K, Kim HS, Choi JD, Kim SH: Tumor necrosis factor alpha-induced interleukin-32 is positively regulated via the Syk/protein kinase Cdelta/JNK pathway in rheumatoid synovial fibroblasts. Arthritis Rheum 2009, 60(3):678-685, 3.

33. Nishida $A$, Andoh $A$, Inatomi $O$, Fujiyama $Y$ : Interleukin-32 expression in the pancreas. J Biol Chem 2009, 284(26):17868-17876.
34. Heinemeyer $T$, Wingender $E$, Reuter I, Hermjakob H, Kel AE, Kel OV, Ignatieva EV, Ananko EA, Podkolodnaya OA, Kolpakov FA, et al: Databases on transcriptional regulation: TRANSFAC, TRRD and COMPEL. Nucleic Acids Res 1998, 26(1):362-367.

35. Tudhope SJ, Catley MC, Fenwick PS, Russell RE, Rumsey WL, Newton R, Barnes PJ, Donnelly LE: The role of IkappaB kinase 2, but not activation of NF-kappaB, in the release of CXCR3 ligands from IFN-gammastimulated human bronchial epithelial cells. J Immunol 2007, 179(9):6237-6245.

36. Aggeli IK, Gaitanaki C, Beis I: Involvement of JNKs and p38-MAPK/MSK1 pathways in $\mathrm{H}_{2} \mathrm{O}_{2}$-induced upregulation of heme oxygenase-1 mRNA in H9c2 cells. Cell Signal 2006, 18(10):1801-1812.

37. Teng $\mathrm{CH}$, Huang WN, Meng TC: Several dual specificity phosphatases coordinate to control the magnitude and duration of JNK activation in signaling response to oxidative stress. J Biol Chem 2007, 282(39):28395-28407.

38. Zhang S, Lin Y, Kim YS, Hande MP, Liu ZG, Shen HM: c-Jun N-terminal kinase mediates hydrogen peroxide-induced cell death via sustained poly (ADP-ribose) polymerase-1 activation. Cell Death Differ 2007, 14(5):1001-1010.

39. Kumar S, Sun X, Wedgwood S, Black SM: Hydrogen peroxide decreases endothelial nitric oxide synthase promoter activity through the inhibition of AP-1 activity. Am J Physiol Lung Cell Mol Physiol 2008, 295(2) L370-377.

40. Kim HA, Jeon SH, Seo GY, Park JB, Kim PH: TGF-beta1 and IFN-gamma stimulate mouse macrophages to express BAFF via different signaling pathways. J Leukoc Biol 2008, 83(6):1431-1439.

41. Liu L, Wang Y, Fan Y, Li CL, Chang ZL: IFN-gamma activates CAMP/PKA/ CREB signaling pathway in murine peritoneal macrophages. J Interferon Cytokine Res 2004, 24(6):334-342.

42. Hu X, Chen J, Wang L, Ivashkiv LB: Crosstalk among Jak-STAT, Toll-like receptor, and ITAM-dependent pathways in macrophage activation. $J$ Leukoc Biol 2007, 82(2):237-243.

43. Hu X, Paik PK, Chen J, Yarilina A, Kockeritz L, Lu TT, Woodgett JR, Ivashkiv LB: IFN-gamma suppresses IL-10 production and synergizes with TLR2 by regulating GSK3 and CREB/AP-1 proteins. Immunity 2006, 24(5):563-574.

44. Ahmad R, Qureshi HY, El Mabrouk M, Sylvester J, Ahmad M, Zafarullah M: Inhibition of interleukin 1-induced matrix metalloproteinase 13 expression in human chondrocytes by interferon gamma. Ann Rheum Dis 2007, 66(6):782-789.

45. Strassheim D, Riddle SR, Burke DL, Geraci MW, Stenmark KR: Prostacyclin inhibits IFN-gamma-stimulated cytokine expression by reduced recruitment of CBP/p300 to STAT1 in a SOCS-1-independent manner. J Immunol 2009, 183(11):6981-6988.

46. Zhang JJ, Vinkemeier U, Gu W, Chakravarti D, Horvath CM, Darnell JE Jr: Two contact regions between Stat 1 and CBP/p300 in interferon gamma signaling. Proc Natl Acad Sci USA 1996, 93(26):15092-15096.

47. Du Z, Wei L, Murti A, Pfeffer SR, Fan M, Yang CH, Pfeffer LM: Nonconventional signal transduction by type 1 interferons: the NF-kappaB pathway. J Cell Biochem 2007, 102(5):1087-1094.

48. Pokrovskaja K, Panaretakis T, Grander D: Alternative signaling pathways regulating type I interferon-induced apoptosis. J Interferon Cytokine Res 2005, 25(12):799-810.

49. Li H, Gade P, Xiao W, Kalvakolanu DV: The interferon signaling network and transcription factor C/EBP-beta. Cell Mol Immunol 2007, 4(6):407-418

50. Blanchette J, Abu-Dayyeh I, Hassani K, Whitcombe L, Olivier M: Regulation of macrophage nitric oxide production by the protein tyrosine phosphatase Src homology 2 domain phosphotyrosine phosphatase 1 (SHP-1). Immunology 2009, 127(1):123-133.

51. Zhang $H$, Forman $H J$ : Signaling pathways involved in phase II gene induction by alpha, beta-unsaturated aldehydes. Toxicol Ind Health 2009, 25(4-5):269-278.

52. Kamei Y, Xu L, Heinzel T, Torchia J, Kurokawa R, Gloss B, Lin SC, Heyman RA Rose DW, Glass CK, et al: A CBP integrator complex mediates transcriptional activation and AP-1 inhibition by nuclear receptors. Cell 1996, 85(3):403-414.

53. Benbrook DM, Jones NC: Heterodimer formation between CREB and JUN proteins. Oncogene 1990, 5(3):295-302.

54. Bai X, Kim SH, Azam T, McGibney MT, Huang H, Dinarello CA, Chan ED: IL32 is a host protective cytokine against Mycobacterium tuberculosis in 
differentiated THP-1 human macrophages. J Immunol 2010,

184(7):3830-3840

55. Netea MG, Azam T, Ferwerda G, Girardin SE, Walsh M, Park JS, Abraham E,

Kim JM, Yoon DY, Dinarello CA, et al: IL-32 synergizes with nucleotide

oligomerization domain (NOD) 1 and NOD2 ligands for IL-1beta and IL-6

production through a caspase 1 dependent mechanism. Proc Natl Acad

Sci USA 2005, 102(45):16309-16314

56. Choi JD, Bae SY, Hong JW, Azam T, Dinarello CA, Her E, Choi WS, Kim BK, Lee CK, Yoon DY, et al: Identification of the most active interleukin-32 isoform. Immunology 2009, 126(4):535-542.

doi:10.1186/1465-9921-13-19

Cite this article as: Kudo et al:: Oxidative stress induced Interleukin-32

mRNA expression in human bronchial epithelial cells. Respiratory

Research 2012 13:19.

Submit your next manuscript to BioMed Central and take full advantage of:

- Convenient online submission

- Thorough peer review

- No space constraints or color figure charges

- Immediate publication on acceptance

- Inclusion in PubMed, CAS, Scopus and Google Scholar

- Research which is freely available for redistribution

Submit your manuscript at www.biomedcentral.com/submit
() Biomed Central 